\title{
Lymphoid and non-lymphoid cells in the epithelium and lamina propria of intestinal
} mucosa of pigs

\author{
H J Rothkötter, T Kirchhoff, R Pabst
}

\begin{abstract}
The jejunum and ileum of 5 day old and adult normal pigs and of $\mathbf{4 5}$ day old germ free pigs were used to study the lymphocyte pools in the epithelium and lamina propria by sequential treatments with EDTA, four hours, and 12 hours of collagenase treatment. In adult animals the incubation of the jejunal wall with EDTA resulted in mean (SD) $26.8(10.9) \times 10^{6}$ intraepithelial lymphocytes per $g$ of tissue. The ileal wall gave lower cell yields. After complete digestion of the lamina propria by collagenase a further yield of $35.2(10 \cdot 2) \times 10^{6} / \mathrm{g}$ lymphocytes was achieved. The separation of the gut wall from 5 day old pigs resulted in a 10-fold lower total lymphocyte yield, and the tissue was totally digested after four hours of collagenase treatment. Many eosinophils and mast cells were found in the suspensions from adult animal tissues after the collagenase treatment; $4 \cdot 7 \times 10^{6} / \mathrm{g}$ and $4.8 \times 10^{6} / \mathrm{g}$, respectively. The suspensions after 12 hour collagenase incubation contained up to $30 \%$ plasma cells. Almost all cells isolated by EDTA incubation were $\mathrm{CD8}^{+} \mathbf{T}$ cells. After collagenase incubation $\mathrm{CD4}^{+}$and $\mathrm{CD8}^{+} \mathrm{T}$ lymphocytes were found in all animal groups, and in adult animals up to $20 \%$ surface $\mathrm{Ig}^{+}$cells were harvested. When the incorporation of the thymidine analogue bromodesoxyuridine was used to study the lymphocyte production in vivo 3 to $7 \%$ lymphocytes in the epithelium were labelled 24 hours later (lamina propria $\mathbf{T}$ lymphocytes about $1 \%$ ). In this study lymphoid as well as non-lymphoid cells have been analysed in mucosal cell suspensions. The absolute cell yield per gram of mucosal tissue is a basis to estimate the pool sizes of intraepithelial and lamina propria lymphocytes. (Gut 1994; 35: 1582-1589)
\end{abstract}

Lymphocytes in the epithelium and lamina propria of the intestinal mucosa play an important part in the induction and maintenance of intestinal immune reactions and in the development of oral tolerance. ${ }^{12}$ They are dynamic cell pools with subsets of $\mathrm{T}$ and surface or cytoplasmic immunoglobulin positive cells, or both occurring with different incidences during the antenatal and postnatal development of enteric function. ${ }^{3-5}$ Mucosal lymphocytes have often been studied, either using immunohistology or suspensions of separated cells. ${ }^{67}$ Intraepithelial lymphocytes can be isolated easily by incubation of the gut mucosa with EDTA $^{89}$ whereas the separation of lamina propria lymphocytes requires tissue treatment by enzymes. ${ }^{1011}$ Although the subsequential isolation of intraepithelial and lamina propria lymphocytes is a standard method in mucosal immunology, there are still several questions concerning these techniques. A remarkable cell loss has been seen after purification steps (gradient centrifugation, filtration), ${ }^{12} 13$ which might cause an artificial enrichment of particular cell subsets. The yield of lymphoid cells isolated from the epithelium and lamina propria is often not indicated or it remains unclear how the lymphocytes were differentiated in the suspensions. It is also debatable whether lamina propria cell suspensions are representative of all the subcompartments of this microanatomically complex part of the gut wall, when the tissue is not digested totally to isolate all lymphoid cells from the mucosa. Furthermore, many studies have dealt solely with mucosal $\mathrm{T}$ cells, and very few data are available on the percentages of Ig isotype positive lymphocytes or plasma cells in mucosal cell suspensions. ${ }^{12-14}$ Finally, obvious limitations in obtaining human mucosal tissue mean that only few comparative data exist on cell yield and composition in different parts of the small intestine.

This study was performed to elucidate these different aspects. The omnivorous pig was chosen as the experimental animal because its gastrointestinal tract is comparable with that of humans in several aspects, and pigs have been used to examine the postnatal development of intestinal enzymes. ${ }^{15}$ Similar patterns of the postnatal appearance of lymphocytes in the lamina propria have been seen in humans and pigs. ${ }^{34}$ For these reasons, pigs were used for cell separation experiments with the following aims: isolation of all cells in the mucosa by complete digestion of the gut tissue; characterisation and quantification of the subsets of $T$ and $\mathrm{Ig}^{+}$lymphoid cells and the non-lymphoid cells in the resulting suspensions; and analysis of the steps in the separation process at which particular cell types are released from the tissue. In this model, it was also possible to study the influence of age and enteric microbial antigens on the cell compositions and separation kinetics in using conventional and germ free reared pigs of different ages. In addition, the percentage of newly formed lymphocytes in the mucosal cell suspensions was determined by incorporation of the thymidine analogue bromodesoxyuridine 
(BrdU). This was of particular importance because little is known about the origin, cell turnover, and the life span of the lymphocytes in the epithelium and lamina propria, and the data that have been published are controversial. ${ }^{6}{ }^{16-19}$ The results obtained are a basis for comparison with cell separation experiments in normal and diseased human gut mucosa.

\section{Methods}

In the first group normal 5 day old German Landrace piglets $(n=6)$ were examined. The second group consisted of germ free German Landrace piglets ( $n=6,45$ days old), which were obtained from Professor Dr Amtsberg, Department of Microbiology, Veterinary School of Hanover. The rearing conditions of these pigs have been described previously. ${ }^{20}$ Adult Göttingen minipigs ( $n=8,14$ months old) were used as a third group. The in vivo proliferation of intraepithelial and lamina propria lymphocytes was studied in another adult group of minipigs $(n=6,9$ months of age). These animals received a single intra-

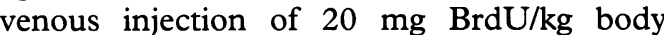
weight (Sigma, Deisenhofen, Germany) and were tested one day later. All animals were killed by an overdose of thiobarbiturate (Trapanal, Byk Gulden, Konstanz, Germany). Standard representation parts of the jejunum (50 $\mathrm{cm}$ distal to the duodenojejunal flexure) and of the ileum $(10 \mathrm{~cm}$ proximal to the continuous ileal Peyer's patch) without macroscopically visible Peyer's patch tissue were removed and examined immediately.

The mucosal cell separation used is a modification of methods described earlier. ${ }^{1021}$ After intensive rinsing with $\mathrm{Ca}^{++}$and $\mathrm{Mg}^{++}$ free Hank's balanced salt solution (Seromed Biochrom, Berlin, Germany) the gut samples were opened. If present, lymphoid follicles and Peyer's patches were excised and discarded. The weight and area of the sample were measured. Between 5 and $10 \mathrm{~g}$ of gut tissue were used for the incubation. After stripping, the mucosa was cut into small pieces $(0.5 \mathrm{~cm} \times 0.5 \mathrm{~cm})$. All separation steps were performed in a shaking waterbath $(120 \mathrm{rpm})$ at $37^{\circ} \mathrm{C}$. Each sample was incubated twice for one hour in a conical flask containing $25 \mathrm{ml}$ $\mathrm{Ca}^{++}$and $\mathrm{Mg}^{++}$free Hanks's balanced salt solution supplemented with 1.26 mmol EDTA and $0.94 \mathrm{mmol}$ dithiotreitol (Sigma, Deisenhofen, Germany) and antibiotics (100 $\mathrm{IU} / \mathrm{ml}$ penicillin, $100 \mu \mathrm{g} / \mathrm{ml}$ streptomycin, 20 $\mu \mathrm{g} / \mathrm{ml}$ gentamycin, $0.5 \mu \mathrm{g} / \mathrm{ml}$ amphotericin, Seromed) to remove the epithelium and to isolate intraepithelial lymphocytes. In contrast with earlier studies, the enzymic digestion of the connective tissue was performed in two steps to isolate cells from the lamina propria. Firstly, the tissue was incubated in $25 \mathrm{ml}$ RPMI 1640 containing 5\% fetal calf serum, $20 \mathrm{mmol}$ HEPES (both Seromed), $0.15 \mathrm{mg} / \mathrm{ml}$ collagenase (no 103586, lot 11888023-94 $0.225 \mathrm{U} / \mathrm{mg}$, Boehringer, Mannheim, Germany), $0 \cdot 1 \mathrm{mg} / \mathrm{ml}$ DNAse (Boehringer), $0.1 \mathrm{mg} / \mathrm{ml}$ trypsin inhibitor (Sigma), and antibiotics (see above) for four hours at $37^{\circ} \mathrm{C}$.
Secondly, the incubation was repeated using new medium of the same composition for 12 hours overnight at $37^{\circ} \mathrm{C}$. The next morning many of the gut samples of the adult pigs were completely digested, in some experiments the remaining tissue fragments were pushed through a steel mesh $(200 \mu \mathrm{m}$ pore size) and the resulting suspension was collected. After each step, the cells in the supernatant were filtered through a stainless steel sieve and collected in $50 \mathrm{ml}$ centrifugation tubes. The suspensions were washed twice (400 g, 10 min) and resuspended in RPMI 1640 containing $0.1 \mathrm{mg} / \mathrm{ml}$ DNAse. The cells were then transferred to a known amount of RPMI 1640 supplemented with DNAse. In some experiments, representative tissue fragments were examined by routine histological tests at the different stages of the separation procedure. The cells of the two EDTA incubations were pooled as the first fraction (EDTA fraction). The second fraction was obtained after the short four hour collagenase treatment, and the 12 hour overnight incubation resulted in the third cell fraction. To exclude possible detrimental effects of the incubation procedures on the lymphoid cells, in one experiment ficoll hypaque separated blood lymphocytes and in two further experiments cells from mesenteric lymph nodes were incubated using the same separation procedure. The effects of these treatments on the control suspensions were analysed by comparing their phenotype before and after the incubation steps using flow cytometry.

Lymphocyte counts were performed in a haemocytometer using a phase contrast microscope at $\times 500$ magnification and the yields of lymphocytes per gram (g) of tissue calculated. Giemsa stained cytospots were used to determine the percentage of small lymphocytes, large lymphocytes, granular lymphocytes, plasma cells, eosinophils, and mast cells. Without further purification, the lymphocyte subpopulation indices were determined in the cell suspensions by flow cytometry (FACScan, Becton Dickinson, Heidelberg, Germany) using monoclonal antibodies against pig lymphocyte surface antigens (CD2 (pan T cells in pigs), $\mathrm{CD} 4, \mathrm{CD} 8$, antipig $\mathrm{IgA}$, antipig $\operatorname{IgM}$, macrophages (mAb 74-22-15), ${ }^{22}{ }^{23}$ with a phycoerythrin labelled second stage antibody (goat antimouse b-phycoerythrin, Dianova, Hamburg, Germany). In forward/side scatter dot plots, a lymphocyte gate was determined for each suspension. The cells in the gate positive for each antibody were determined using fluorescence histograms.

A modification of the method described by Westermann et al ${ }^{24}$ was used to detect the incorporated BrdU and the lymphocyte subsets in the proliferation study. On cytospots, the subsets were determined using CD2, CD8, antipig $\operatorname{IgA}$, and antipig $\operatorname{IgM}$ monoclonal antibodies, a secondary antibody (Z259, Dako, Hamburg, Germany), and the alkaline phosphatase anti-alkaline phosphatase technique (APAAP D651, Dako) with fast blue dye. The DNA was then denaturated with formamide/sodium hydroxide. The incorporated 


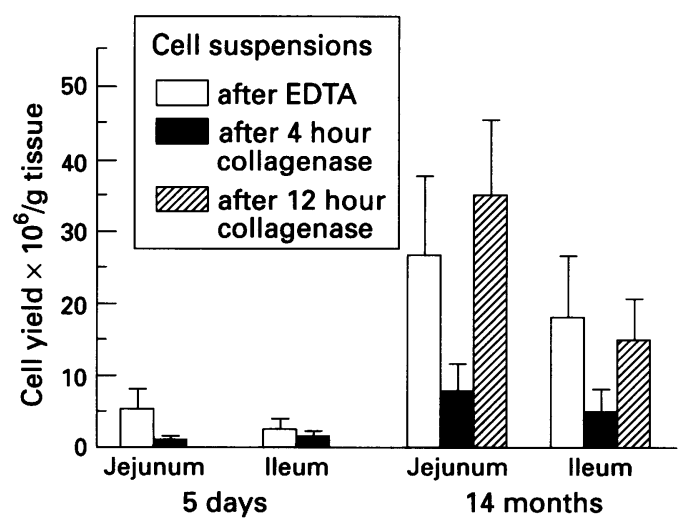

Figure 1: Lymphocyte yield per gram of jejunal and ileal mucosa in 5 day old and adult (14 month) normal pigs. The lymphocytes were isolated by two $\times$ one hour EDTA treatment and by a short (four hour) and an overnight (12 hour) incubation with collagenase. The data are shown in this and the subsequent illustrations as mean (SD). The cell yield was calculated based on lymphocyte counts made by phase contrast microscopy.

BrdU was determined using a monoclonal antibody against BrdU (anti-BrdU, Becton Dickinson, Heidelberg, Germany) and the immunoperoxidase method (Z259 and PAP P850 complex, Dako). The cells positive for each subset were counted on the cytospots and each checked for BrdU incorporation.

For statistical analyses of results, mean (SD) of the data were calculated. The MannWhitney $U$ test was used and $\mathrm{p}<0.05$ was taken as significant.

\section{Results}

SEPARATION PROCESS AND CELL YIELD

Histological sections of tissue fragments, acquired during the separation procedure, showed that after EDTA treatment all epithelial cells of the villi and most of the intraepithelial lymphocytes had been removed. After the four hour incubation with collagenase the connective tissue of the villi had been digested, but the lamina propria between the crypts was still intact. The tissue of 5 day old pigs and of germ free animals was already totally dispersed after this incubation step. In all other samples of adult pigs, the whole tissue was digested at the end of the experiments after a further 12 hours of collagenase incubation. The lymphocyte viability was greater than $90 \%$ in the trypan blue exclusion test. Phase contrast microscopy was an efficient method to count the number of lymphoid cells in the resulting suspensions. The lymphocyte yield was expressed in lymphocytes per gram of tissue. One gram was equivalent to $5 \cdot 2(0 \cdot 9)$ $\mathrm{cm}^{2}$ gut tissue in 14 month old pigs. Figure 1 shows the lymphocyte yield of 5 day and of 14 month old pigs. Most cells were isolated in the first and the third fractions (EDTA incubation and 12 hour collagenase treatment). Fewer lymphocytes were obtained from the ileal than the jejunal mucosa (Fig 1). In 45 day old germ free animals, the cell yield was comparable with that of 5 day old normal pigs (jejunum first fraction: $3 \cdot 8(2 \cdot 8) \times 10^{6}$, second fraction: $\left.1.5(2) \times 10^{6}\right)$. Lymphocyte numbers isolated from the tissues of the 9 month old pigs were about $50 \%$ lower than from the 14 month old animals.

\section{CELL DIFFERENTIATION}

The cytospots contained debris and many dead epithelial cells and these were excluded from the evaluation. While the percentages of lymphocytes, granular lymphocytes, eosinophils, and mast cells were easily determined, it was difficult to differentiate between large lymphocytes and immature plasma cells. Small lymphocytes and eosinophils predominated in the jejunum and ileum of 5 day old animals (for example, second fraction of ileum: $\quad$ lymphocytes $=36.9 \quad(8.5) \%$, eosinophils $=54 \cdot 1(10 \cdot 2) \%)$ and of germ free pigs. In the jejunum of 14 month old pigs (Fig 2 ), the first EDTA fraction contained many small or granular lymphocytes and a significant proportion of eosinophils (4.0 (2.3)\%). In the second fraction after four hours of collagenase treatment, the percentage of granular lymphocytes from the jejunum had decreased but more eosinophils were found $(12.9(3.5) \%)$. Further collagenase incubation for 12 hours resulted in an increase in the plasma cells and mast cells (Fig 2). In the ileum of 14 month old pigs the comparative number of small lymphocytes was two thirds and that of plasma cells only one third of the percentages seen in the jejunal samples. In the ileum, however, about a threefold increase in the percentage of eosinophils was found after EDTA and collagenase incubation. There were no differences in the cellular compositions of the jejunal as well as the ileal samples between tissues of the 9 and 14 month old pigs. In all animal groups the percentage of eosinophils was significantly higher in the ileum. The absolute numbers of mast cells and eosinophils were calculated based on the lymphocyte counts and the percentage of lymphoid cells in the differential cell counts. In the ileum of 14 month old pigs, the first fraction contained $3.2(1.9) \times 10^{6}$ eosinophils/g, and the fractions after collagenase treatment up to $4.7 \times 10^{6}$ eosinophils/g.
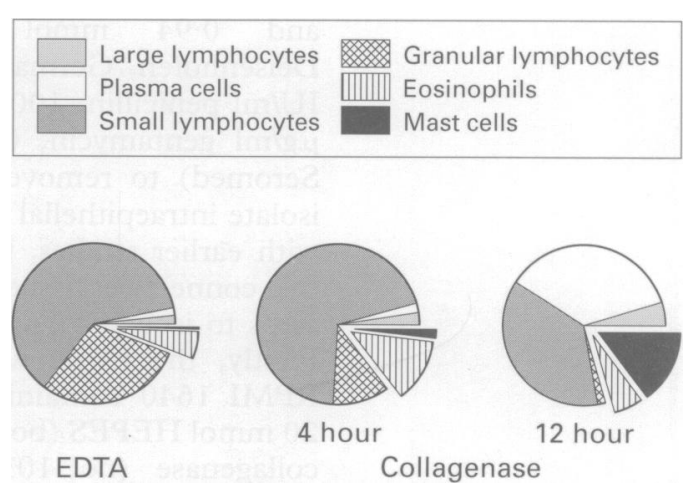

Figure 2: Mean percentage of lymphoid cells, eosinophils, and mast cells in jejunal cell suspensions isolated from the mucosa of 14 month old pigs after EDTA and two subsequent collagenase incubations. The cell differentiation was performed on Giemsa stained cytospots. 

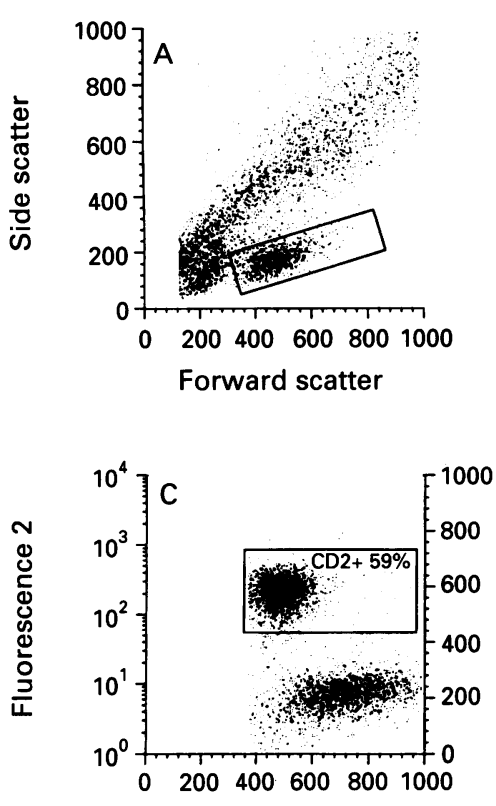

Forward scatter
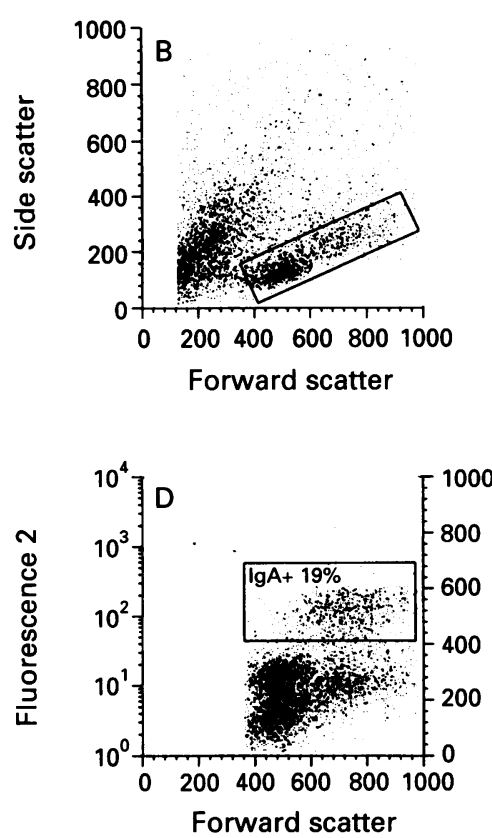

Figure 3: Flow cytometric analysis of mucosal cell suspensions isolated from the jejunum of a 14 month old pig. $(A)$ and $(B)$ Dot plots showing the forward and side scatter values of all isolated cells. (A) Intraepithelial lymphocytes (IEL): cells isolated by EDTA treatment; (B) lamina propria lymphocytes (LPL): cells isolated during the overnight 12 hour collagenase incubation. The delineated populations show the isolated lymphocytes (lymphocyte gate), in the LPL panel some of the lymphocytes have a higher forward scatter value, which shows that after collagenase incubation a population of larger cells is isolated from the lamina propria. (C) and (D) Same cell population as in (B) after gating on lymphocytes. The cells were stained using $C D 2^{+}$and $\operatorname{Ig} A^{+}$antibodies and

immunofluorescence. The dot plots show the values of the forward scatter and of the fluorescence intensity. (C) LPL, CD2 ${ }^{+} T$ cells: the window shows the cells positive for the. $T$ cell marker, many of the cells are small (lower forward scatter values); (D) LPL, IgA cells: the surface Ig $A^{+}$cells in the window have higher forward scatter values pointing to their large size. There is a population of cells with larger forward scatter values that were not stained by $T$ cell antibodies and were negative for surface immunoglobulin, which are putative plasma cells.
Some differences were found in the lymphocyte subsets studied, for example after incubation the percentage of $\mathrm{CD}_{2}{ }^{+}$cells was reduced by $<5 \%$, but about $10 \%$ less surface $\mathrm{Ig}^{+}\left(\mathrm{sIg}^{+}\right)$ cells were found. In all suspensions tested, the expression values of the lymphocyte antigens were not affected by the incubation procedure.

The lymphoid cells in the tissue suspensions were identified and gated using their characteristic forward and side scatter properties in the flow cytometer (Fig 3). As young and germ free animals had few lymphocytes/g tissue (Fig 1), the gating was difficult, because the small numbers of lymphocytes were engulfed in a large proportion of red blood cells, dead enterocytes, and small tissue fragments. Thus, the gated population contained a certain number of events that were not lymphoid cells. This resulted in small percentages of lymphocyte subsets in young and germ free pigs. The comparative number of $\mathrm{CD} 2^{+}$lymphocytes was low, especially in the ileum (Table I). In both adult groups (9 and 14 months) the gating was easier (Fig 3). In the third fraction of these pigs, a significant proportion of lymphoid cells was found with higher forward scatter values, consistent with their larger cell size (Fig 3), and immunofluorescent staining showed that some of these larger cells were sIg $^{+}$(Fig 3). In this fraction in 9 month old pigs, however, between 5 and $25 \%$ of the cells in the gate were not labelled by $\mathrm{T}$ or macrophage antibodies and expressed no $\mathrm{sIg}^{+}$ (Table I). As the forward scatter values of these unlabelled cells were higher than those of the $\mathrm{CD} 2^{+}$cells (Fig 3), it is unlikely that these were red blood cells in the gated population.

Figure 4 and Table I show the percentages of lymphocyte subsets in jejunal cell suspensions of 5 day and 14 month old animals. The number of macrophages was always lower than $5 \%$, therefore this subset was not included in Table I. In 5 day old animals a larger proportion of $\mathrm{CD}^{+}$lymphocytes was found in the

TABLE I Proportions of lymphocyte subsets in mucosal cell suspensions

\begin{tabular}{|c|c|c|c|c|c|c|c|}
\hline & & \multicolumn{3}{|l|}{ fejunum } & \multicolumn{3}{|l|}{ Ileum } \\
\hline & & \multirow[b]{2}{*}{$E D T A$} & \multicolumn{2}{|l|}{ Collagenase } & \multirow[b]{2}{*}{$E D T A$} & \multicolumn{2}{|l|}{ Collagenase } \\
\hline & & & 4 hour & 12 hour & & 4 hour & 12 hour \\
\hline 5 days $(\%)$ & $\begin{array}{l}\text { CD2 } \\
\text { CD4 } \\
\text { CD8 } \\
\text { sIgA } \\
\text { sIgM }\end{array}$ & $\begin{array}{c}59.9(11.9) \\
7 \cdot 0(2 \cdot 4) \\
20 \cdot 2(14 \cdot 1) \\
2 \cdot 8(2 \cdot 4) \\
2.5(1.9)\end{array}$ & $\begin{array}{r}45 \cdot 8(8 \cdot 0) \\
6 \cdot 1(1 \cdot 6) \\
6 \cdot 4(6 \cdot 7) \\
2 \cdot 6(2 \cdot 1) \\
2 \cdot 0(1 \cdot 0)\end{array}$ & ND & $\begin{array}{c}36 \cdot 8(13 \cdot 0) \\
3 \cdot 2(1 \cdot 8) \\
5.9(4 \cdot 5) \\
1 \cdot 7(1 \cdot 3) \\
3 \cdot 4(4 \cdot 2)\end{array}$ & $\begin{array}{c}46 \cdot 1(0.5) \\
6.5(3.4) \\
12.9(11 \cdot 0) \\
2 \cdot 2(1.9) \\
2 \cdot 6(2.9)\end{array}$ & ND \\
\hline Germ free $(\%)$ & $\begin{array}{l}\text { CD2 } \\
\text { CD4 } \\
\text { CD8 } \\
\text { sIgA } \\
\text { sIgM }\end{array}$ & $\begin{array}{c}55 \cdot 9(6 \cdot 7) \\
20 \cdot 7(30 \cdot 2) \\
4 \cdot 2(4 \cdot 8) \\
1.5(0 \cdot 7) \\
1 \cdot 2(1 \cdot 3)\end{array}$ & $\begin{array}{c}71 \cdot 1(20 \cdot 5) \\
8 \cdot 8(2 \cdot 0) \\
15 \cdot 3(12 \cdot 1) \\
1 \cdot 7(2 \cdot 1) \\
2 \cdot 7(1.9)\end{array}$ & ND & $\begin{array}{c}12 \cdot 8(10.9) \\
3 \cdot 1(3 \cdot 4) \\
1.3(0.5) \\
0.4(0.1) \\
0.8(0 \cdot 1)\end{array}$ & $\begin{array}{c}74.2(11.0) \\
11.2(3.5) \\
23.6(10.4) \\
2.0(1.8) \\
2.9(0.9)\end{array}$ & ND \\
\hline 9 months (\%) & $\begin{array}{l}\text { CD2 } \\
\text { CD4 } \\
\text { CD8 } \\
\text { sIgA } \\
\text { sIgM }\end{array}$ & $\begin{array}{c}86.0(6.5) \\
7.2(3.3) \\
67.5(10.4) \\
1.8(0.9) \\
1.6(1.1)\end{array}$ & $\begin{array}{c}90.9(10.0) \\
33.4(12.6) \\
52.7(13.7) \\
2.7(2.6) \\
6.6(9.5)\end{array}$ & $\begin{array}{c}57 \cdot 6(20 \cdot 0) \\
14 \cdot 0(6 \cdot 8) \\
32 \cdot 6(24 \cdot 7) \\
5 \cdot 9(3 \cdot 6) \\
4 \cdot 1(3 \cdot 4)\end{array}$ & $\begin{array}{c}84 \cdot 1(7 \cdot 7) \\
3.9(1.0) \\
54 \cdot 5(10 \cdot 1) \\
1.9(1 \cdot 0) \\
1.8(1.4)\end{array}$ & $\begin{array}{r}93.4(5.9) \\
30.7(9.4) \\
50.4(9.6) \\
2.8(1.4) \\
1.9(1.2)\end{array}$ & $\begin{array}{c}77.5(8.1) \\
15.9(6.5) \\
39.6(10.8) \\
3.7(1.5) \\
2.3(1.3)\end{array}$ \\
\hline 14 months $(\%)$ & $\begin{array}{l}\text { CD2 } \\
\text { CD4 } \\
\text { CD8 } \\
\text { sIgA } \\
\text { sIgM }\end{array}$ & $\begin{array}{r}95 \cdot 1(4 \cdot 0) \\
5.6(2 \cdot 2) \\
85 \cdot 7(8 \cdot 8) \\
2 \cdot 2(1 \cdot 4) \\
1.3(0 \cdot 7)\end{array}$ & $\begin{array}{l}93 \cdot 6(2 \cdot 4) \\
47 \cdot 5(21 \cdot 6) \\
86 \cdot 0(16 \cdot 5) \\
3.4(2 \cdot 0) \\
2 \cdot 1(1 \cdot 3)\end{array}$ & $\begin{array}{c}84 \cdot 4(12 \cdot 8) \\
26 \cdot 5(4 \cdot 1) \\
61 \cdot 1(29 \cdot 7) \\
12 \cdot 9(5 \cdot 13) \\
4 \cdot 3(2 \cdot 4)\end{array}$ & $\begin{array}{c}95 \cdot 0(1 \cdot 2) \\
11 \cdot 5(10 \cdot 6) \\
80 \cdot 1(10 \cdot 4) \\
1.9(0 \cdot 6) \\
1 \cdot 1(0 \cdot 8)\end{array}$ & $\begin{array}{c}94.9(2 \cdot 3) \\
51 \cdot 5(26 \cdot 3) \\
83.6(17 \cdot 1) \\
2.7(1 \cdot 5) \\
1.4(1 \cdot 0)\end{array}$ & $\begin{array}{c}89 \cdot 3(4 \cdot 4) \\
37 \cdot 0(12 \cdot 3) \\
72 \cdot 9(23 \cdot 7) \\
8 \cdot 7(3 \cdot 2) \\
2 \cdot 5(1 \cdot 8)\end{array}$ \\
\hline
\end{tabular}

Percentages of lymphocyte subsets (mean (SD)) in the mucosal cell suspensions of the jejunum and ileum in 5 day old normal, 45 day old germ free, and 9 and 14 month old normal pigs. The results were obtained by flow cytometric analysis of epithelial cell suspensions isolated by EDTA incubation and of lamina propria suspensions separated by two subsequent collagenase incubations. $\mathrm{ND}=$ In 5 day old and in germ free animals no 12 hour collagenase incubation was performed as the mucosa was completely digested after the four hour collagenase incubation. 

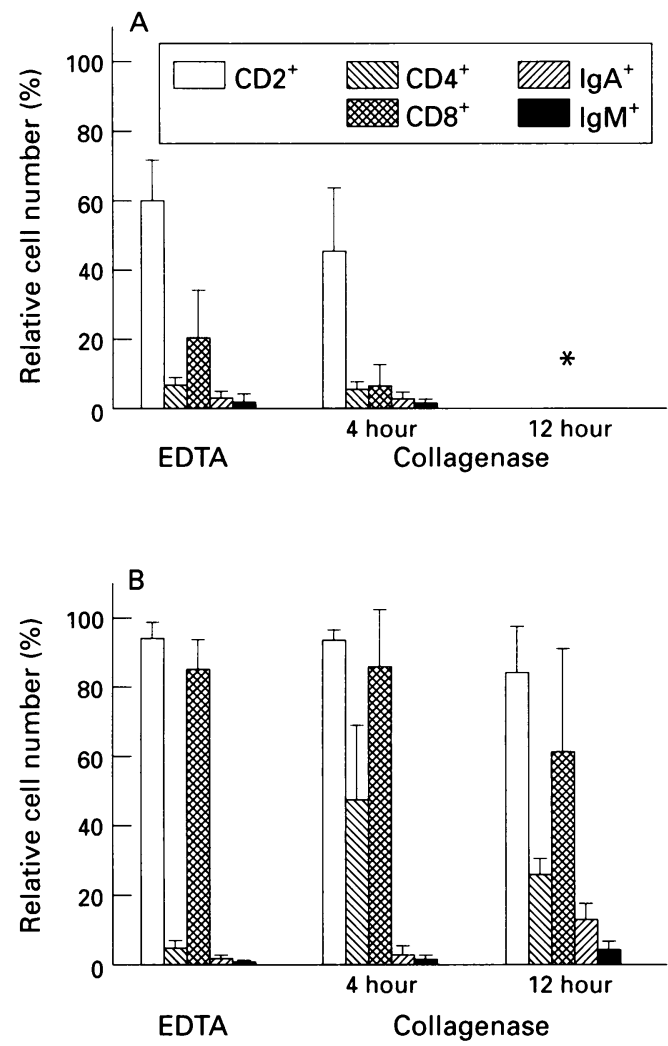

Figure 4: Percentage of $C D 2^{+}, C D 4^{+}, C D 8^{+}, \operatorname{sIg} A^{+}$, and sIgM ${ }^{+}$cells in mucosal cell suspensions isolated after EDTA and two collagenase incubations (four hours and 12 hours). Suspensions isolated from the jejunum of $(A) 5$ day old piglets and (B) 14 month old pigs. * In 5 day old animals the tissue was already digested after the first collagenase incubation and the second collagenase incubation was not performed.

EDTA fraction than in the collagenase fraction. The sum of the comparative number of $\mathrm{CD}^{+}$and $\mathrm{CD}^{+}$cells was less than the percentage of $\mathrm{CD} 2^{+}$cells, providing evidence of a $\mathrm{CD} 2^{+} \mathrm{CD}^{-} \mathrm{CD}^{-}$cell population in young pigs. Very few $\operatorname{sIg}^{+}$cells were found (Fig 4A, Table I). In the ileal suspensions from the same animals and in the suspensions from 45 day old germ free pigs, a comparable $\mathrm{CD} 2^{+} / \mathrm{sIg}^{+}$subset pattern was seen (Table I). In germ free pigs more $\mathrm{CD}^{+}$than $\mathrm{CD}^{+}$were harvested after EDTA incubation (Table I), but immunohistological examinations showed that almost all of these $\mathrm{CD}^{+}$cells were located in the lamina propria (results not included).

In jejunal and ileal samples of adult pigs (9 and 14 months), the lymphocyte composition of the three cell suspensions showed considerable differences (Fig 4B, Table I). As expected, the suspensions after short and overnight collagenase treatment (second and third fraction) contained more $\mathrm{CD}^{+}{ }^{+}$cells than the EDTA fraction. In comparison with $\mathrm{CD} 2^{+}$cells, the high percentages of $\mathrm{CD}^{+}$and $\mathrm{CD}^{+}$cells show that in the gut samples of these adult pigs there must be a proportion of CD4 CD8 double positive cells, especially in the fraction after short collagenase treatment (Fig 4B, Table I). In the first two suspensions, a small number of $\mathrm{sIg}^{+}$cells was detected, but in the third fraction there was an increased percentage of $\operatorname{sIgA}{ }^{+}$and $\operatorname{sIgM}{ }^{+}$cells (Table I). In 9 month old animals there was a proportion of non- $\mathrm{T} /$ non-sIg ${ }^{+}$cells in the cell fraction after 12 hours of collagenase incubation, as the sum of $\mathrm{CD}^{+}{ }^{+} \mathrm{T}$ cells, sIgA ${ }^{+}$and $\operatorname{sIgM}{ }^{+}$cells was less than $100 \%$ (Table I).

Table I shows the percentages of subsets in the jejunal and ileal suspensions of all four animal groups. Although the comparative subset distribution is important, in view of the differences in the sizes of each compartment the absolute numbers (for example, cell yield per $g$ of tissue) are equally important, especially for comparing the results of different studies. Table II shows the absolute numbers of lymphocytes in each subset per $\mathrm{g}$ of tissue in the jejunum and ileum in all four experimental groups. Very few cells, mostly $\mathrm{CD} 2^{+}$, were found in the ileum of germ free pigs. In 9 month old animals, a significant proportion of $\mathrm{sIg}^{+}$cells was isolated after the EDTA

TABLE II Absolute numbers per gram of tissue in each subset in lymphocyte suspensions from the mucosa

\begin{tabular}{|c|c|c|c|c|c|c|c|}
\hline & & \multicolumn{3}{|l|}{ fejunum } & \multicolumn{3}{|l|}{ Ileum } \\
\hline & & \multirow[b]{2}{*}{$E D T A$} & \multicolumn{2}{|l|}{ Collagenase } & \multirow[b]{2}{*}{$E D T A$} & \multicolumn{2}{|l|}{ Collagenase } \\
\hline & & & 4 hour & 12 hour & & 4 hour & 12 hour \\
\hline 5 days $\times 10^{6} / \mathrm{g}$ & $\begin{array}{l}\text { CD2 } \\
\text { CD4 } \\
\text { CD8 } \\
\text { sIgA } \\
\text { slgM }\end{array}$ & $\begin{array}{l}3.3(2 \cdot 1) \\
0.4(0 \cdot 3) \\
1.2(0 \cdot 9) \\
0 \cdot 2(0 \cdot 2) \\
0.2(0 \cdot 2)\end{array}$ & $\begin{aligned} & 0.6(0 \cdot 4) \\
& 0.1(0.1) \\
& 0 \cdot 1(0 \cdot 1) \\
&<0 \cdot 1 \\
&<0.1\end{aligned}$ & ND & $\begin{array}{l}1 \cdot 1(1 \cdot 0) \\
0 \cdot 1(0 \cdot 1) \\
0 \cdot 2(0 \cdot 3) \\
0 \cdot 1(0 \cdot 1) \\
0 \cdot 1(0 \cdot 2)\end{array}$ & $\begin{array}{l}0 \cdot 7(0 \cdot 3) \\
0 \cdot 1(0 \cdot 1) \\
0 \cdot 2(0 \cdot 3) \\
0 \cdot 1(0 \cdot 1) \\
0 \cdot 1(0 \cdot 1)\end{array}$ & ND \\
\hline Germ free $\times 10^{6} / \mathrm{g}$ & $\begin{array}{l}\text { CD2 } \\
\text { CD4 } \\
\text { CD8 } \\
\text { sIgA } \\
\text { sIgM }\end{array}$ & $\begin{array}{r}2 \cdot 0(1 \cdot 2) \\
0 \cdot 4(0 \cdot 4) \\
0 \cdot 2(0 \cdot 2) \\
<0 \cdot 1 \\
0 \cdot 1(0 \cdot 1)\end{array}$ & $\begin{array}{r}1 \cdot 4(2 \cdot 0) \\
0 \cdot 2(0 \cdot 2) \\
0 \cdot 2(0 \cdot 2) \\
<0.1 \\
0.1(0 \cdot 1)\end{array}$ & ND & $\begin{aligned} & 0 \cdot 2(0 \cdot 1) \\
< & 0 \cdot 1 \\
< & 0 \cdot 1 \\
< & 0 \cdot 1 \\
< & 0 \cdot 1\end{aligned}$ & $\begin{aligned} & 0 \cdot 1(0 \cdot 1) \\
< & 0 \cdot 1 \\
< & 0 \cdot 1 \\
< & 0 \cdot 1 \\
< & 0 \cdot 1\end{aligned}$ & ND \\
\hline 9 months $\times 10^{6} / \mathrm{g}$ & $\begin{array}{l}\text { CD2 } \\
\text { CD4 } \\
\text { CD8 } \\
\text { sIgA } \\
\text { sIgM }\end{array}$ & $\begin{array}{r}15 \cdot 8(6 \cdot 3) \\
1 \cdot 3(0 \cdot 6) \\
12 \cdot 1(3 \cdot 9) \\
0 \cdot 3(0 \cdot 2) \\
0.3(0 \cdot 2)\end{array}$ & $\begin{array}{l}3 \cdot 3(2 \cdot 8) \\
1 \cdot 0(0 \cdot 5) \\
2 \cdot 1(2 \cdot 0) \\
0 \cdot 1(0 \cdot 2) \\
0 \cdot 2(0 \cdot 3)\end{array}$ & $\begin{array}{l}7 \cdot 1(6 \cdot 1) \\
1.7(1 \cdot 1) \\
3 \cdot 8(3 \cdot 6) \\
0.9(0 \cdot 8) \\
0.7(0.8)\end{array}$ & $\begin{array}{c}10 \cdot 4(4 \cdot 0) \\
0 \cdot 4(0 \cdot 2) \\
6 \cdot 7(2 \cdot 6) \\
0 \cdot 3(0 \cdot 2) \\
0 \cdot 2(0 \cdot 2)\end{array}$ & $\begin{array}{l}3.9(0.6) \\
1 \cdot 3(0 \cdot 7) \\
2 \cdot 1(0.5) \\
0 \cdot 1(0 \cdot 1) \\
0 \cdot 1(0 \cdot 1)\end{array}$ & $\begin{array}{l}5 \cdot 6(2 \cdot 1) \\
1 \cdot 2(0 \cdot 6) \\
2 \cdot 8(1 \cdot 2) \\
0.3(0 \cdot 2) \\
0.2(0 \cdot 1)\end{array}$ \\
\hline 14 months $\times 10^{6} / \mathrm{g}$ & $\begin{array}{l}\text { CD2 } \\
\text { CD4 } \\
\text { CD8 } \\
\text { sIgA } \\
\text { sIgM }\end{array}$ & $\begin{array}{c}25 \cdot 7(10 \cdot 7) \\
1.3(0 \cdot 6) \\
23.5(8 \cdot 2) \\
0.7(0.7) \\
0 \cdot 4(0.3)\end{array}$ & $\begin{array}{l}7 \cdot 4(3 \cdot 7) \\
2 \cdot 9(1 \cdot 2) \\
6 \cdot 1(2 \cdot 9) \\
0 \cdot 3(0 \cdot 3) \\
0 \cdot 2(0 \cdot 1)\end{array}$ & $\begin{array}{c}29 \cdot 7(9 \cdot 8) \\
8 \cdot 6(3.9) \\
21.9(14 \cdot 1) \\
4 \cdot 8(2 \cdot 7) \\
1.6(1 \cdot 2)\end{array}$ & $\begin{array}{r}17.7(7.5) \\
1.6(1.6) \\
14 \cdot 8(6.5) \\
0.3(0 \cdot 1) \\
0.2(0 \cdot 1)\end{array}$ & $\begin{array}{l}4 \cdot 9(2 \cdot 9) \\
1 \cdot 9(1 \cdot 2) \\
4 \cdot 3(2 \cdot 8) \\
0 \cdot 1(0 \cdot 1) \\
0 \cdot 1(0 \cdot 1)\end{array}$ & $\begin{array}{r}13 \cdot 3(6 \cdot 4) \\
4.5(3 \cdot 1) \\
11 \cdot 7(7 \cdot 8) \\
1.2(0 \cdot 6) \\
0.3(0 \cdot 2)\end{array}$ \\
\hline
\end{tabular}

Absolute yield of lymphocyte subsets/g gut tissue (mean (SD)) in the same experiments shown in Table I. The results were calculated based on the lymphocyte cell yield determined in phase contrast microscopy and the percentages of lymphocyte subsets given in Table I (ND, see Table I). 


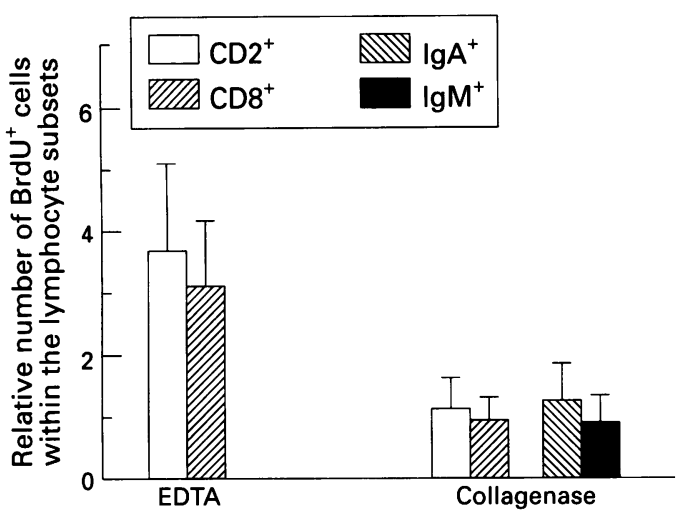

Figure 5: Newly formed cells in cell suspensions obtained after the EDTA and 12 hour collagenase treatment steps of 9 month old pig tissues. The animals were given a single dose of BrdU and the intestines were sampled 24 hours later. Using an immunocytochemical double stain on cytospots, the relative numbers of $C D 2^{+}, C D 8^{+}, I g A^{+}$, and IgM $\mathrm{M}^{+}$cells that had incorporated BrdU were determined.

incubation, but in both adult animal groups the largest proportion of $\operatorname{sIgA}^{+}$and $\operatorname{sIgM}^{+}$ cells was found after the 12 hour collagenase incubation.

\section{IN VIVO PROLIFERATION STUDY}

In the first cell fraction, only the proliferation of $\mathrm{T}$ and $\mathrm{CD}^{+}$cells was analysed because there were too few $\mathrm{Ig}^{+}$cells in this compartment (Fig 5). In this first jejunal and ileal cell fraction equal numbers of $T$ cells had incorporated BrdU. In the third cell fraction, the proportion of proliferating lymphocytes was lower $(\mathrm{T}$ cells $=1 \cdot 1(0 \cdot 5) \%)$. Small numbers of $\mathrm{Ig}^{+}$cells were $\mathrm{BrdU}^{+}\left(\operatorname{IgA}^{+}=1.2(0.6) \%\right.$; $\left.\operatorname{IgM}^{+}=0.8(0 \cdot 5) \%\right)$.

\section{Discussion}

This study was performed to analyse the kinetics of separation of intraepithelial and lamina propria lymphocytes and to study the influence of age and microbial stimuli on the development of these cells during postnatal life. In all experiments, the mucosa was completely digested and the resulting cell suspensions were not purified. The separation protocol had no important effects on the cells with respect to the parameters studied. Important findings concerning the technique were made that are often not taken into account in mucosal cell isolation. Firstly, within the cell suspensions isolated with the epithelium significant numbers of eosinophils and $\operatorname{sIg}^{+}$cells were present, in addition to many granular lymphocytes and the expected large proportion of $\mathrm{CD}^{+}$cells. Under normal circumstances, eosinophils and $\mathrm{Ig}^{+}$cells do not occur in the intestinal epithelium, as confirmed by histological examination. Their presence in the first cell fraction is clear evidence that these suspensions also contain cells from the lamina propria, perhaps immediately under the epithelium. Secondly, after collagenase incubation, granular lymphocytes were seen, which are normally only found in the epithelium of the mucosa. ${ }^{2526}$ Their occurrence after the first collagenase incubation is evidence of a contamination from the epithelial cell pool. Morphological examination of the cell suspensions using Giemsa stained cytospots was essential for these findings; the results could not have been obtained by flow cytometry alone. Thus, it is important in evaluating published data to take into consideration how intraepithelial or lamina propria cell suspensions have been isolated and purified and whether the compositions of the cell populations have been checked before analysis using sensitive techniques. ${ }^{19} 27$ Thirdly, it was found advantageous to split the collagenase incubation into two sequential steps. Regarding the total cell composition (lymphoid/nonlymphoid cells) and the lymphocyte subset composition, the suspensions after a short collagenase treatment (four hours) were more comparable with intraepithelial cell fractions. Only after an overnight collagenase incubation (12 hours) were all cell populations in the lamina propria harvested $\left(\mathrm{CD} 4{ }^{+}\right.$lymphocytes, $\mathrm{sIg}^{+}$cells, plasma cells, and mast cells). This reflects the histological structure of the mucosa. During the first collagenase incubation, the villus lamina propria was preferentially dissociated, as seen in histological sections of the tissue fragments. In immunohistological examinations, however, the $\mathrm{Ig}^{+}$ cells were mainly found in the crypts of the mucosa. ${ }^{428}$ In agreement with this distribution, very few $\mathrm{sIg}^{+}$cells were found after the first collagenase incubation. The complete dissociation of the crypt areas was necessary to isolate most $\mathrm{Ig}^{+}$cells. Based on these findings, an incomplete digestion of the lamina propria will selectively reduce the proportion of $\mathrm{sIg}^{+}$ cells in lamina propria suspensions.

One further aspect was that in young animals, the bulk of cells was already obtained after two hour EDTA incubation, even without collagenase treatment, because there is less connective tissue. In mice, a comparable quick separation has been seen. ${ }^{12}$ Therefore, it is much more difficult to obtain pure intraepithelial lymphocyte suspensions in young animals or in smaller animals like rodents. These findings are also relevant for separation experiments in inflamed tissue. The question remains, however, whether the incubation protocol should be adapted to the tissue under examination or whether a standard protocol should always be used. Harvesting the separated cells at short intervals was an advantage, because it prevented cell loss resulting from cell death in the incubation flask and made it possible to analyse the cell suspensions in detail. If the tissue localisation of a specific cell subpopulation is unclear, an immunohistological examination can help to find out if the cells in the suspensions originate from the epithelium or the lamina propria.

As the number of intraepithelial or lamina propria lymphocytes is low in gut samples of young or germ free animals, ${ }^{49}$ the high proportion of epithelial cells and small tissue fragments may disturb the flow cytometric analysis of the cell suspensions. This results in low percentages of lymphocyte subsets (Table I). Although not performed in this study, the 
proportion of lymphocytes in the gated suspension can be determined using an antiCD45 monoclonal antibody. Another difficulty was the occurrence of a population of cells not stained by $\mathrm{T}$ or anti-Ig antibodies. These nonT/non-sIg ${ }^{+}$cells had higher forward scatter values than the $\mathrm{CD} 2^{+}$cells (Fig 3 ) and it can be discounted that they were red blood cells. Plasma cells have little if any immunoglobulin on their surface, ${ }^{30}$ so they may not be stained when anti-Ig antibodies are used in immunofluorescence. The non-T/non-sIg ${ }^{+}$cells with large forward scatter values in the third suspensions in adult animals (Fig 3) are probably plasma cells. The discrepancy between the percentage of $\mathrm{sIg}^{+}$cells (flow cytometric analysis, Fig 3, 4B, and Table I) and the large numbers of plasma cells (Giemsa cytospots, Fig 2) supports this hypothesis. So far there is no explanation why the 9 month old animals had more non-T/ non-sIg ${ }^{+}$cells than the 14 month old pigs. Further experiments should include techniques to detect intracytoplasmic and surface immunoglobulin to analyse all intestinal lymphoid cells of the B cell family.

In humans, no data are available on cell separation in very young children. In young pigs the cell yield was only $10 \%$ of that obtained in older animals. In germ free piglets of 45 days of age, cell yield and subset patterns were comparable with those in 5 day old normal animals. Together with earlier data, 429 this is evidence that live microbial antigens are the main stimuli leading to a postnatal increase in the $\mathrm{T}$ lymphocyte compartments in the gut wall. The occurrence of a $\mathrm{CD} 2^{+} \mathrm{CD} 4^{-} \mathrm{CD} 8^{-}$ lymphocyte subset in the flow cytometric analysis of suspensions obtained from young animals is confirmation of a comparable finding in immunohistology. 4 It cannot be excluded that these cells are $\gamma / \delta \mathrm{T}$ cell receptor positive cells, as in pigs there is evidence for a $\mathrm{CD}^{+} \gamma / \delta \mathrm{T}$ cell subset. ${ }^{31}$ Lymphocytes double positive for CD4 and CD8 have been seen not only in the lamina propria of pigs but also among the intraepithelial lymphocytes in rats. ${ }^{32}$ The finding of the $\mathrm{CD} 4{ }^{+} \mathrm{CD} 8^{+}$ lymphocyte subset in the lamina propria of adult animals showed that these lymphocytes are activated to a high extent, because $\mathrm{CD} 4^{+} \mathrm{CD}^{+}$lymphocytes were found after activation of pig lymphocytes. ${ }^{33}$

The relative proportions of mast cells to lymphoid cells isolated from the mucosa in the third fraction are comparable with results obtained by histological examination using specific detection methods for mucosal mast cells. $^{34}$ The isolation technique is an easy method to determine the population of mast cells and other non-lymphoid immune cells in all mucosal cell suspensions. Large numbers of non-lymphoid cells can be isolated for functional tests in vitro. In relative numbers, the small intestine of 5 day old pigs contains many more non-lymphoid immune cells than lymphocytes. In particular, eosinophils are the first cells extravasating into the intestinal mucosa and performing non-specific immune responses to the antigens appearing in the gut after birth.
The turnover of the intraepithelial lymphocytes is not yet clear. It has been reported that these cells proliferate in vivo ${ }^{16} 1819$ and in vitro. ${ }^{8}$ In contrast, in a study using the monoclonal antibody $\mathrm{Ki}-67$, which stains proliferating cells, Halstensen et al ${ }^{17}$ could not detect positively stained cells in the normal human intestinal epithelium. In our experiments many more intraepithelial $T$ cells were seen in the cell cycle during the 24 hour observation period than $\mathrm{T}$ or $\mathrm{Ig}^{+}$cells in the lamina propria. Intradermal lymphocytes have a comparable production rate with those in the intestinal epithelium, but the number of $\mathrm{BrdU}^{+}$cells in peripheral lymph nodes was $10-$ fold lower. ${ }^{35}$ It is a matter of speculation whether all labelled cells were produced in the epithelium or lamina propria of the small intestine or whether they migrated into these tissue sites within the 24 hour period after the BrdU injection, or a mixture of both.

The total cell yield seen in adult pigs $\left(7 \times 10^{7} / \mathrm{g}\right)$ was within the range reported for human mucosa. ${ }^{101336}$ It was difficult to compare these data as few studies stated whether the whole tissue had been digested and how many cells had been lost during density gradient centrifugation. ${ }^{13}$ In this study the absolute cell yield was expressed per gram of gut tissue, that is the weight of the mucosa and the muscle layers. It is suggested that the cell yield per gram of stripped mucosa is possibly a better basis for comparison as changes in the weight of the musculature would not then influence the results. The absolute cell yield per gram of tissue can be used as a basis to estimate the size of the mucosal lymphocyte pools. In this study, the similar cell numbers in adult animals after the EDTA and collagenase treatments show that the intraepithelial and lamina propria cell pools are comparable in these pigs. Based on these results, it can be extrapolated that the small intestines of 14 month old pigs weighing about $50 \mathrm{~kg}$ contain a total of $7 \times 10^{9}$ intraepithelial and lamina propria lymphocytes per metre (weight of $1 \mathrm{~cm}$ of small intestine $=1 \mathrm{~g}$; total lymphocyte yield per $\mathrm{g}=$ about $7.0 \times 10^{7} / \mathrm{g} ; 100 \times 7.0 \times 10^{7} \mathrm{lym}-$ phocytes $=7 \times 10^{9}$ cells $/ \mathrm{m}$ ). This is low in comparison with the absolute number of $10 \times 10^{9}$ plasma cells per metre reported in the human small intestine ${ }^{37}$ However, the order of the cell pool size is comparable. It has been calculated that a $30 \mathrm{~kg}$ pig has a total of $321 \times 10^{9} \mathrm{lym}-$ phocytes. ${ }^{38}$ As the small intestine of 14 month old animals is 7 to 10 metres in length, more than $10 \%$ of the total lymphocytes of the pigs body are distributed in the epithelium and lamina propria of the small intestinal mucosa.

In conclusion, the results show the importance of a careful separation protocol, modified according to the normal or diseased state of the tissue examined. A combination of lymphocyte counts, calculation of the cell yield/g, morphological cell differentiation, and lymphocyte subset analysis is essential to acquire reliable data about lymphoid and non-lymphoid cells in the compartments of the mucosa. These studies, especially those in young piglets, are important for clinical research. They can serve 
as a model for the examination of evolving mucosal cell populations in postnatal development when the body is first facing microbial and nutritional antigens in the gut lumen.

The study was supported by the Deutsche Forschungsgemeinschaft, SFB 280 'Gastrointestinal Barrier', Project C 1. The authors thank Professor Dr Amtsberg of the Department of Microbiology, Veterinary School of Hanover for providing the intestines of the germ free animals and $\mathrm{Dr} F$ Klobasa of the Institute for Animal Breeding and Behaviour (FAL), Mariensee, Neustadt for providing some of the pigs. Monoclonal antibodies were kindly supplied by Drs A Bianchi (Lelystad, The Netherlands), R M Binns (Cambridge, UK), and A Saalmüller (Tübingen, Germany). The skilful technical assistance of $S$ Faßbender, A Herden, and S Schlecht, the help of Dr N N Barman, and the correction of English and secretarial help by $S$ Fryk are gratefully acknowledged.

These data were presented in part at the 7th International These data were presented in part at the 7th Internatior
Congress of Mucosal Immunology, August 1992, Prague.

1 Brandtzaeg P, Halstensen TS, Kett K, Krajci P, Kvale D, Rognum TO, et al. Immunobiology and immunopathology of human gut mucosa: humoral immunity and intraepithelial lymphocytes. Gastroenterology 1989; 97: intraepith

2 Harvey J, Jones DB. Human mucosal T-lymphocyte and macrophage subpopulations in normal and inflamed intestine. Clin Exp Allergy 1991; 21: 549-60.

3 Perkkiö M, Savilahti E. Time of appearance of immunoglobulin-containing cells in the mucosa of the neonatal intestine. Pediatr Res 1980; 14: 953-5.

4 Rothkötter HJ, Ulbrich H, Pabst R. The postnatal development of gut lamina propria lymphocytes: number, proliferation, and $\mathrm{T}$ and $\mathrm{B}$ cell subsets in conventional and germ-free pigs. Pediatr Res 1991; 29: 237-42.

5 Spencer J, Isaacson PG, Walker-Smith JA, MacDonald TT. Heterogeneity in intraepithelial lymphocyte subpopulations in fetal and postnatal human small intestine. $\mathcal{f}$ Pediatr Gastroenterol Nutr 1989; 9: 173-7.

6 Cerf-Bensussan N, Guy-Grand D. Intestinal intraepithelial lymphocytes. Gastroenterol Clin North Am 1991; 20: 549-75.

7 James SP. Mucosal T-cell function. Gastroenterol Clin North Am 1991; 20: 597-612

8 Cerf-Bensussan N, Guy-Grand D, Griscelli C. Intraepithelial lymphocytes of human gut: isolation, characterisation and study of natural killer activity. Gut 1985; 26: $81-8$.

9 Mosley RL, Klein JR. A rapid method for isolating murine intestine intraepithelial lymphocytes with high yield and purity. F Immunol 1992; 156: 19-26.

purity. 7 Immunol 1992 ; 156: $19-26$.
10 Bull DM, Bookman MA. Isolation and functional characterization of human intestinal mucosal lymphoid cells. $\mathcal{f}$ Clin Invest 1977; 59: 966-74.

11 Zeitz M, Greene WC, Peffer NJ, James SP. Lymphocytes isolated from the intestinal lamina propria of normal nonhuman primates have increased expression of genes associated with T-cell activation. Gastroenterology 1988; 94: 647-55.

12 Van der Heijden PJ, Stok W. Improved procedure for the isolation of functionally active lymphoid cells from the murine intestine. F Immunol Methods 1987; 103: 161-7.

13 Selby WS, Janossy G, Bofill M, Jewell DP. Intestinal lymphocyte subpopulations in inflammatory bowel disease: an analysis by immunohistological and cell isolation an analysis by immunohistolog

14 Bookman MA, Bull DM. Characteristics of isolated intestinal mucosal lymphoid cells in inflammatory bowel disease. Gastroenterology 1979; 77: 503-10.

15 Shulman RJ, Henning SJ, Nichols BL. The miniature pig as an animal model for the study of intestinal enzyme development. Pediatr Res 1988; 23: 311-5.

16 Cuff CF, Rubin DH, Cebra JJ. Analysis of mucosal lymphocyte proliferation in vivo by incorporation of 5-Bromo-2'-Deoxyuridine. F Immunol 1993; 150: 37A.

17 Halstensen TS, Brandtzaeg P. Activated T lymphocytes in the celiac lesion: non-proliferative activation (CD25) of
$\mathrm{CD}^{+} \alpha / \beta$ cells in the lamina propria but proliferation $(\mathrm{Ki}-67)$ of $\alpha / \beta$ and $\gamma / \delta$ cells in the epithelium. Eur $\mathcal{f}$ Immunol 1993; 23: 505-10.

18 Röpke C, Everett NB. Kinetics of intraepithelial lymphocytes in the small intestine of thymus-deprived mice and antigen-deprived mice. Anat Rec 1976; 185: 101-8.

19 Yamamoto M, Fujihashi K, Beagley KW, McGhee JR, Kiyono H. Cytokine synthesis by intestinal intraepithelial lymphocytes: both $\gamma / \delta \mathrm{T}$ cell receptor-positive and $\alpha / \beta \mathrm{T}$ cell receptor-positive $\mathrm{T}$ cells in the G1 phase of cell cycle produce IFN- $\gamma$ and IL-5. F Immunol 1993; 150: 106-14.

20 Dziaba KA, Lambrecht G, Petzoldt K. Intestinal and serum antibody response in gnotobiotic piglets to oral immunization with Escherichia coli. Comp Immunol Microbiol Infect Dis 1985 ; 8: 267-72.

21 James SP, Graeff AS. Spontaneous and lymphokineinduced cytotoxic activity of monkey intestinal mucosal lymphocytes. Cell Immunol 1985; 93: 387-97.

22 Lunney JK, Pescovitz MD. Differentiation antigens of swine lymphoid tissues. In: Trnka Z, Miyasaka M, eds. Differentiation antigens in lymphohemopoietic tissues. New York: Dekker, 1988: 421-51.

23 Lunney JK. Characterization of swine leukocyte differentiation antigens. Immunol Today 1993; 14: 147-8.

24 Westermann J, Ronneberg S, Fritz FJ, Pabst R. Proliferation of lymphocyte subsets in the adult rat: a comparison of different lymphoid organs. Eur $\mathcal{F}$ Immunol 1989; 19: 1087-93.

25 Marsh MN, Leigh RJ, Loft DE, Garner GV, Gordon DB. Studies of intestinal lymphoid tissue X-observations on granular epithelial lymphocytes (gEL) in normal and diseased human jejunum. Virchows Arch $[A]$ 1988; 412: 365-70.

26 Wilson AD, Stokes CR, Bourne FJ. Morphology and functional characteristics of isolated porcine intraepithelial lymphocytes. Immunology 1986; 59: 109-13.

27 Guy-Grand D, Vanden Broecke C, Briottet C, MalassisSeris M, Selz F, Vassalli P. Different expression of the recombination activity gene RAG-1 in various populations of thymocytes, peripheral $\mathrm{T}$ cells and gut thymusindependent intraepithelial lymphocytes suggests two independent intraepithelial lymphocytes suggests two pathways of T cell

28 Baklien K, Brandtzaeg P. Immunohistochemical characterization of local immunoglobulin formation in Crohn's disease of the ileum. Scand $f$ Gastroenterol 1976; 11: 447-57.

29 Guy-Grand D, Griscelli C, Vassalli P. The mouse gut T lymphocyte, a novel type of T cell. $\mathcal{F}$ Exp Med 1978; 148: 1661-77.

30 Brown SL, Morrison SL. Regulation of the production of secretory and membrane immunoglobulin during lymphocyte development. Clin Immunol Immunopathol lymphocyte devel

31 Reddehase MJ, Saalmüller A, Hirt W. $\gamma / \delta$ T-lymphocyte subsets in swine. Curr Top Microbiol Immunol 1991; 173:

32 Takimoto H, Nakamura T, Takeuchi M, Sumi Y, Tanaka $\mathrm{T}$, Nomoto $\mathrm{K}$, et al. Age-associated increase in number of $\mathrm{CD}^{+}{ }^{+} \mathrm{CD} 8^{+}$intestinal intraepithelial lymphocytes in rats. Eur F Immunol 1992; 22: 159-64.

33 Saalmüller A, Reddehase MJ, Bühring HJ, Jonjic S, Koszinowski UH. Simultaneous expression of CD4 and CD8 antigens by a substantial proportion of resting porcine $\mathrm{T}$ lymphocytes. Eur $f$ Immunol 1987; 17: porcine T

34 Pabst R, Beil W. Mast cell heterogeneity in the small intestine of normal, gnotobiotic and parasitized pigs. Int Arch Allergy Appl Immunol 1989; 88: 363-6.

35 Fritz FJ, Pabst R, Binns RM. Lymphocyte subsets and their proliferation in a model for a delayed-type hypersensitivity reaction in the skin. Immunology 1990; 71: 508-16.

36 Rüthlein J, Heinze G, Auer IO. Anti-CD2 and anti-CD3 induced $T$ cell cytotoxicity of human intraepithelial and lamina propria lymphocytes. Gut 1992; 33: 1626-32.

37 Brandtzaeg $\mathrm{P}$. Overview of the mucosal immune system. Curr Top Microbiol Immunol 1989; 146: 13-25.

38 Pabst R, Trepel F. Quantitative evaluation of the total number and distribution of lymphocytes in young pigs. Blut 1975; 31: 77-86. 